JURNAL ILMIAH KOMPUTERISASI AKUNTANSI, Vol. 13, No. 1, Juli 2020, pp. 89 - 99

p-ISSN : 1979-116X (print)

e-ISSN : 2614-8870 (online)

http://journal.stekom.ac.id/index.php/kompak

\title{
Analysis of Islamic Banks in Indonesia and Malaysia Using CAMEL
}

Pipin Lestari ${ }^{1}$, Widhian Hardiyanti ${ }^{2}$

${ }^{1}$ Universitas Stikubank

Jl. Trilomba Juang No 1 Semarang, (62-24) 8451976, e-mail: pipinlestari21 @ gmail.com

${ }^{2}$ Universitas Stikubank

Jl. Trilomba Juang No 1 Semarang, (62-24) 8451976, e-mail: widhian@edu.unisbank.ac.id

\begin{tabular}{|c|c|}
\hline ARTICLE INFO & abstract \\
\hline $\begin{array}{l}\text { Article history: } \\
\text { Received } 30 \text { Mei } 2020 \\
\text { Received in revised form } 15 \text { Juni } 2020 \\
\text { Accepted } 17 \text { Juli } 2020 \\
\text { Available online } 28 \text { Juli } 2020\end{array}$ & $\begin{array}{l}\text { indonesia is a country with the largest Moslem } \\
\text { population in asean, but in the aspect of islamic } \\
\text { banking, indonesia is still lacking, comparing with } \\
\text { malaysia. this study compares the financial } \\
\text { performance of islamic banking in both countries } \\
\text { with a method called camel.there are five aspects } \\
\text { of this camel method, approach, namely capital } \\
\text { adequacy (car), asset quality (npf), management } \\
\text { quality (npm), earnings (roa, bopo), and liquidity } \\
\text { (fdr). the analytical tool used is a different t-test to } \\
\text { find out whether there are differences or not } \\
\text { between the financial performance of indonesian } \\
\text { and malaysian shari'ah. From the results of thedata } \\
\text { analysis with the Independent t-test three variables } \\
\text { namely (NPF, NPM, BOPO) showed significant } \\
\text { differences, while the variables (CAR, ROA, and } \\
\text { FDR) there were no significant differences } \\
\text { between Indonesian and Malaysian banks. }\end{array}$ \\
\hline
\end{tabular}

Keywords: Financial performance, CAMEL, Indonesia, Malaysia.

\section{Introduction}

Indonesia is the country with the largest, Moslem population in ASEAN, not only in ASEAN but also in all overthe world, around more than $85 \%$ of the total population of indonesia are moslems. This potential possessed should make Indonesia the centerof the world islamic finance development. Along with the development of the global economy, significant growth in the Islamic banking industry in the era of the ASEAN Economic Community (AEC) was also influenced by politics, culture, geography, defense and security (Wibowo, 2015). Although it is developing rapidly in terms of the syari'ahfinancial system globally, the condition of the shariafinancial industry in Indonesia is still stagnant, in terms of asset growth and the market share of sharia financial Indonesia is still below other Muslim majority countries. Based on the 2019 Islamic Finance Development Report (IFDI) which is an index to measure the development of the sharia financial industry and also AS a barometer of the health level of the global shariafinancial industry, Indonesia ranks 4th from 10th in the previous year. Malaysia is in first place, followed by Bahrain and the Arab Emirate Union. The three countries hold a portion of Islamic financial assets by $65 \%$ in 2018 and for Islamic financial industry assets in Malaysia to grow by 5\% in 2018, while Indonesia grew by $3 \%$ from US \$ 2.4 trillion in 2017 to US \$ 2.5 trillion in 2018 . Indicators assessed by IFDI include; quantitative growth, knowledge, governance, Corporate Social Responsibility (CSR) and public awareness.

Received Mei 23, 2020; Revised Juli 17, 2020; Accepted Juli 28, 2020 
The tight competitiveness between Indonesian Islamic banking and other Muslim-majority countries, requires Islamic banks to understand of theweaknesses and strengths of their own companies in order to compete with other banking companies in order of reaching the targeted market. strengths and weaknesses will have an impact on the level of health of islamic banks, so it needs to be considered, maintained and improved to maintain the level of public confidence (novera, 2017). assessing the soundness of a bank is very necessary so that management knows what is the problem of a bank and to evaluate the bank's performance so far, and determine the decision taken as a follow-up in solving problems that occur. financial management and stakeholders use financial statements as an analytical tool in assessing the performance or level of soundness of banks, especially in this case is islamic banking.

Measurements to analyze the level of islamic bank's health and often used in previous research before is the camel method. The CAMEL method is an evaluation ranking system for assessing the performance of a bank. This method was first created by the Federal Financial Institutions Examination Board in the United States in November 1979, and then adopted by the National Credit Union Administration in October 1987 (Rastogi \& Singh, 2017). Valuation in the CAMEL method is based on THE ratio analysis OF financial statements, there are five dimensions in this approach, namely Capital Adequacy, Asset Quality, Management Quality, Earnings, and Liquidity. Previous studies using the CAMEL method as a measurement of bank performance were carried out by Kaligis (2013), Rastogi \& Sigh (2017), Jacob (2013), and Paputungan (2015).

\section{Literature review}

\section{Capital Adequacy}

The capital adequacy ratio measures the bank's capital position expressed as the ratio of capital to the assets, where itdetermines the bank's capacity to absorb unexpected losses (Rastogi \& Singh, 2017). Assessment of capital adequacy uses the Capital Adequacy Ratio (CAR) as the main ratio or the Minimum Capital Adequacy Ratio (KPMM) (Paputungan, 2015). CAR shows how far the decline in bank assets can still be covered by available bank capital. CAR provisions of at least $8 \%$ are adopted by Indonesian banks which stipulate bank KPMM in BI Regulation No. 14/18 / PBI / 2012. CAR ratio is calculated by comparing total capital with Risk Weighted Assets (R'WA):

$$
\text { CAR }=\frac{\text { Capital }}{\text { RWA }} \times 100 \%
$$

Many studies use CAR ratioas ratiothat illustrate the capital adequacy of a bank, one of which is Rizkiyah \& Suhandak (2017) that compares the healthiness ofbanks in Islamic banks in Indonesia, Malaysia, UAE, and Kuwait. The results showed that, based on CAR ratios for the health level of the four countries, there were no significant differences. Other studies conducted by Wibowo 2014) compared the performance of Islamic banks in Indonesia, Brunei Darussalam and the Philippines with the same results, namely there were no significant differences in terms of CAR, ROA, ROE, and AGRratiosbetween the financial performance of Indonesia and Brunei Darusalam, while Philipines is the only one with no significant differences of CAR ratio. Some researchers also compared the performance of Islamic banks in Indonesia and Malaysia with the same results, namely Achan \& Chariri (2014), Wibowo (2015) and Hadi et al., (2019).

Having a contrastto research conducted by Widyawati \& Musdholifah (2018) which compared the financial performance of banks in ASEAN, namely Indonesia, Malaysia, Singapore, Thailand, and the Philippines in 2012-2016. This study obtained different results where based on capital indicators with CAR ratios, Indonesian banks were superior compared to the other four ASEAN countries. That still found any different results), based on that case the researcher proposes the following hypothesis:

H1: There is a significant difference from the CAR value at the soundness of Islamic banks in Indonesia and Malaysia.

\section{Asset Quality}

Analyzing the quality of productive assets is also important even though in real banks have substantial capital. In measuring asset quality, there are several ratios that can be used, one of the ratios that describes the quality of assets of a bank is Non-perfoming Financing (NPF). NPF is a ratio that shows the percentage of the number of problem loans (with substandard, doubtful and loss criteria) with the total loans extended by banks. The higher of this ratio,the worse bank's credit quality, so that the number of problem loans increases and there is possibility of a bankrupt bank (novita et al., 2016). the formula to calculate npf is as follows:

JURNAL ILMIAH KOMPUTERISASI AKUNTANSI Vol. 13, No. 1, Juli $2020: 88-99$ 


\section{p-ISSN : 1979-116X e-ISSN : 2614-8870 \\ NPF $=\frac{\text { Total NPF }}{\text { Total Credit }} \times 100 \%$}

A comparative study conducted by Wibowo (2015) states that there is no significant difference in the NPL indicator between the financial performance of banks in Indonesia, Malaysia and Thailand. Different from previous studies, research by Widyawati \& Musdholifah (2018) states that the Indonesian state is better than Malaysia, Singapore, Thailand, and the Philippines in terms of the NPL ratio. Other research was also conducted by Rizkiyah \& Suhandak (2017) where the NPL ratio in Indonesia, Malaysia, Kuwait was very good, while in the uae it was not. Based on these differences, the researcher proposes the following hypothesis:

H2: There is a significant difference from the NPF value on the soundness of Islamic banks in Indonesia and Malaysia.

Management Quality

In this study using a quantitative assessment in the form of a Net Profit Margin (NPM) ratio that can be projected with management aspects. The factor which is the reason for using NPMs to assess bank health is because this ratio is very closely related to management aspects, both in general management and risk management. Net income in general management aspects reflects the measurement of the strategy of the decision being carried out and in its technique is illustrated in the form of a recording, security and supervision system of the bank's operational activities in an effort to obtain optimal operating income. While net income in describing risk management reflects measurements of efforts to minimize liquidity risk, credit risk, operational risk, legal risk, and owner risk from bank operations to obtain optimal operating income (Wahid, 2015). The formula tocalculating the NPM ratio is as follows Jacob (2013) and Paputungan (2016):

$$
\text { NPM }=\frac{\text { Net Profit }}{\text { Net Sales }} \times \mathbf{1 0 0} \%
$$

Several previous studies also used this ratio to measure the health levelof banks between Indonesia and Malaysia. Research conducted by Achan \& Chariri (2014) by taking samples of 31 pure Islamic banks with mixed Islamic banks (conventional banks that open Islamic banks) as many as 31 banks worldwide. This study states that judging from the NPM ratio showsthere is no significant difference between the performance of pure and mixed Islamic banks. This is in line with research conducted by Hadi et al., (2019) with a sample of PT. Bank Mandiri (Indonesia) and MayBank (Malaysia), alsoshowsthere is no significant difference between Bank Mandiri's performance with MayBank and the NPM ratio. Different results occur in research conducted by Rifai (2013) comparing the performance of 3 Islamic banks in Indonesia, seen from the NPM ratio there are significant differences between the three banks. Based on thiscase, the researcher proposes the following hypothesis:

H3: There is a significant difference from the value of NPM in the level of health of Islamic banks in Indonesia and Malaysia.

Earning Aspects (Rentability)

The benchmark of assessing the healthiness of a bank is the bank's ability to make a profit. something need to understand, banks in their operational activities always suffer losses until the losses take up capital. If this happens, the bank cannot be said as a healthy one(Andrianto and Firmansyah, 2019: 387). The assessment in the aspect of profitability or earnings of a bank is based on the calculation of two ratios, including:

a. Ratio of Return on Assets to the total formula:

$$
\text { ROA }=\frac{\text { Profit Before tax }}{\text { Total Assest }} \times \mathbf{1 0 0} \%
$$

Research of thesecomparing banking performance in Indonesia with other countries was conducted by Widyawati \& Musdholifah (2018), Azzahroh et al., (2016), and Hadi et al., (2019) which all stated that there were no significant differences in the performance of Indonesian banks with other countries seen from the ROA ratio, while research by Wibowo (2015), Achan \& Chariri (2014), statedthe opposite. The difference from the results of previous studies encourages researchers to propose a hypothesis as follows: H4a: There is a significant difference from the value of ROA on the level of islamic bank healthin Indonesia and Malaysia.

b. Operating Expense Ratio to Operating Income (BOPO) with the formula:

$$
\text { BOPO }=\frac{\text { Operational Expens }}{\text { Operational Income }} \times \mathbf{1 0 0} \%
$$

In the BOPO ratio, the study of Widyawati \& Musdholifah (2018), Hadi et al., (2019) statedthat there are significant differences between the financial performance of banks in Indonesia and Malaysia. This is 
in line with the study of Achan \& Chariri (2014) where there are also significant differences between the financial performance of pure and mixed sharia banks around the world. based on that case,the researcher proposes the following hypothesis:

H4b: There is a significant difference from the BOPO value in the health level of Islamic banks in Indonesia and Malaysia.

Liquidity

The liquidity aspect in this study is represented by the Financial to Deposit Ratio (FDR) ratio. FDR is used to analyze the ability of banks to meet their obligations (Achan \& Chariri, 2014). In conventional banks the FDR ratio is known as the LDR (Loan to Deposit Ratio) ratio. The calculation of ratio formula) is as follows:

$$
\mathbf{F D R}=\frac{\text { Total Financing }}{\text { Total Third Party Funds }} \times \mathbf{1 0 0} \%
$$

Previous studies that usedthis ratio calculation were Widyawati \& Musdholifah (2018), Achan \& Chariri (2014), Wibowo (2015), and Hadi et al., (2019). The results of the four researchers stated that judging from the FDR ratio, there were significant differences in the performance of banks in Indonesia with other countries such as Malaysia, Thailand and other ASEAN countries, so the researchers put forwardofthe following hypothesis:

H5: There is a significant difference from the value of FDR on the soundness of Islamic banks in Indonesia and Malaysia

\section{Research Methods}

This research is a quantitative study which is a scientific approach in managerial and economic decision making based on data that has been collected and then processed and analyzed into useful information Kuncoro, (2011). In this study, the type of comparative research is comparative research. The object of this study is the annual report (Annual Report) published by Islamic banking registered at the central banks of Indonesia and Malaysia. Indicators to measure the healthiness of shariabanking in the two countries use the CAMEL approach (Capital Adequacy, Asset Quality, Management Quality, Earnings, and Liquidity). CAMEL components were obtained from previous studies.

The population of this study is the banks that carry out their operational activities based on shariahprinciples and are registered in central banks in Indonesia and Malaysia. Sampling from the population of Islamic banking uses purposive sampling. Referring to the specified criteria, the number of samples taken and meeting the criteria is 24 Islamic banks, consisting of 12 Indonesian Islamic banks and 12 Islamic banks in Malaysia. The criteria used are as follows:

Therefore, there are several criteria in sampling this study as follows:

1. A central of general commercial bank in Indo and Malaysia.

2. The annual report can be accessed through the official banking page.

3. General syariah bank which publishing the annual report from 2014-2018.

4. The period in the bank's annual report ends on December 31.

5. Take the same amount of samples between the two countries.

Table 1. List of Research Samples

\begin{tabular}{|c|c|c|c|}
\hline No & Country & The Name of The Islamic Bank & Code \\
\hline 1 & \multirow{10}{*}{ Indonesia } & PT Bank BRI Syariah & BRIS \\
\hline 2 & & PT Bank Syariah Mandiri & BSM \\
\hline 3 & & PT Bank BCA Syariah & BCAS \\
\hline 4 & & PT Bank BNI Syariah & BNIS \\
\hline 5 & & PT Bank Mega Syariah & BMGS \\
\hline 6 & & PT Bank Panin Dubai Syariah & BPDS \\
\hline 7 & & PT Bank Syariah Bukopin & BSB \\
\hline 8 & & PT Bank Muamalat Indonesia & BMUA \\
\hline 9 & & PT Bank Victoria Syariah & BVS \\
\hline 10 & & PT. Bank NTB Syariah & BNTBS \\
\hline
\end{tabular}

JURNAL ILMIAH KOMPUTERISASI AKUNTANSI Vol. 13, No. 1, Juli $2020: 88-99$ 
p-ISSN : 1979-116X e-ISSN : 2614-8870

\begin{tabular}{|c|c|c|c|}
\hline 11 & & PT. Maybank Syaria Indonesia & BMSI \\
\hline 12 & & PT. Bank Tabungan Pensiunan Nasional Syariah & BTPNS \\
\hline 13 & \multirow{12}{*}{ Malaysia } & Affin Islamic Bank Berhad & AIBB \\
\hline 14 & & Al Rajhi Banking \& Investment Corporation (Malaysia) Berhad & ARBB \\
\hline 15 & & Bank Islam Hong Leong Berhad & BIHLB \\
\hline 16 & & Bank Islam Malaysia Berhad & BIMB \\
\hline 17 & & CIMB Islamic Bank Berhad & CIBB \\
\hline 18 & & HSBC Amanah Malaysia Berhad & HAMB \\
\hline 19 & & Kuwait Finance House (Malaysia) Berhad & KFHB \\
\hline 20 & & Maybank Islamic Berhad & MIB \\
\hline 21 & & OCBC Al-Amin Bank Berhad & OAABB \\
\hline 22 & & Public Islamic Bank Berhad & PIBB \\
\hline 23 & & RHB Islamic Bank Berhad & RIBB \\
\hline 24 & & Standard Chartered Saadiq Berhad & SCSB \\
\hline
\end{tabular}

\section{Data analysis technique}

This researches are usingdescriptive analysis method with financial ratio analysis tool with CAMEL method and hypothesis testing with different tests. Different test or independent sample t-test is conducted to analyze data and compare the performance of Indonesian and Malaysian state banks.

\section{Financial Ratio Analysis with CAMEL Method}

In this study, researchers used the CAMEL to measure the level of health of Islamic banks in Indonesia and Malaysia. CAMEL consisting of elements of Capital Adequacy, Asset Quality, Management Quality, Earnings, and Liquidity is proxied by ratios that describe each of these elements, including capital Adequacy Ratio (CAR), Non Perfoming Financing (NPF), Net Profit Margin (NPF), Net Profit Margin (NPM), Return on Assets (ROA), Operating Costs to Operating Income (BOPO), Financial to Deposit Ratio (FDR).

The ratios are calculated on the annual financial statements published by the official banking sites in Indonesia and Malaysia which are the research samples. The annual report that was sampled was a 20142018 report and researchers did not convert currencies in one of the countries of the country studied because currency units had no effect in calculating the CAMEL ratio. Each CAMEL ratio is calculated for an average value of five years to be used as a comparative test variable in the level of soundness in the banks studied.

\section{Descriptive statistics}

Descriptive research is research conducted using numerical and graphical methods to recognize patterns of a number of data of the data number, summarize the information contained in the data, and present the information in the desired form (Kuncoro, 2011: 26). According toGhozali, (2016: 19) descriptive statistical analysis gives an overview of data measured by the average (mean), minimum, maximum, and standard deviation contained in the study, so that it can be used in comparative research between Islamic commercial banks in Indonesia and Malaysia).

\section{Hypothesis}

Hypothesis testing for the comparison between Islamic banking in Indonesia and Malaysia will be carried out with the Independent $t$-test which is also called withthe t-test different test. Hypothesis testing with this test was carried out by several previous researchers, including Hadi et al., (2019), Azzahroh et al., (2016), and Achan \& Chariri (2014).

Independent $\mathrm{t}$-test is used to show how far the influence of one independent variable individually inorder to explain thedependent variable. According to Ghozali (2016: 64) t-test is used to determine whether two unrelated samples have different mean values or not. This testing method has been used in comparative analysis of commercial banks in Indonesia and Malaysia conducted by Azzahroh et al., (2016) and Hadi et al., (2019) as well as comparisons between pure and mixed Islamic banks throughout the world by Achan \& Chariri (2014). 
Decision making on research hypotheses is based on probability or significance values, provided that:

- If the probability is $<0.05$, then $\mathrm{H}$ is rejected or there is an average difference in the two samples or different variance.

- If the probability is $>0.05$, then $\mathrm{H}$ is accepted or there is no average difference in the two study samples or the same variance.

\section{Results and Discussion}

Test results based on CAMEL's financial ratios show that in broad outline, there is no significant difference in the level of health of Islamic banking in Indonesia and Malaysia as seen from the average ranking of the six ratios for five consecutive years with the CAMEL method. This can be seen from table 2 as follows:

Table 2. Average CAMEL Financial Ratios of Bank Indonesia and Malaysia for the 2014-2018 period

\begin{tabular}{|c|c|c|c|c|c|c|c|c|}
\hline No & Country & Code Bank & CAR & NPF & NPM & ROA & BOPO & FDR \\
\hline 1 & \multirow{12}{*}{ Indonesia } & BRIS & 19,49 & 5,35 & 3,55 & 0,50 & 95,08 & 81,59 \\
\hline 2 & & BSM & 14,63 & 5,13 & 3,85 & 0,49 & 94,78 & 79,72 \\
\hline 3 & & BCAS & 30,87 & 0,39 & 4,52 & 0,88 & 89,00 & 90,03 \\
\hline 4 & & BNIS & 17,59 & 2,63 & 9,33 & 1,26 & 87,33 & 85,83 \\
\hline 5 & & BMGS & 20,85 & 2,67 & 5,15 & 1,04 & 93,86 & 93,15 \\
\hline 6 & & BPDS & 19,77 & 4,65 & $-18,67$ & $-1,63$ & 117,06 & 91,18 \\
\hline 7 & & BSB & 17,33 & 5,65 & $-1,10$ & $-0,01$ & 94,34 & 89,49 \\
\hline 8 & & BMUA & 12,92 & 5,15 & 1,25 & 0,49 & 98,29 & 85,56 \\
\hline 9 & & BVS & 18,12 & 6,56 & $-7,68$ & $-1,03$ & 112,54 & 91,47 \\
\hline 10 & & BNTBS & 33,10 & 1,24 & 21,29 & 3,79 & 70,90 & 94,46 \\
\hline 11 & & BMSI & 76,92 & 16,84 & $-19,52$ & $-6,83$ & 139,53 & 85093,01 \\
\hline 12 & & BTPNS & 29,50 & 1,42 & 18,59 & 7,28 & 74,36 & 94,27 \\
\hline 13 & \multirow{12}{*}{ Malaysia } & AIBB & 15,48 & 1,58 & 12,60 & 0,73 & 82,87 & 86,27 \\
\hline 14 & & ARBB & 19,84 & 0,92 & 2,24 & 0,16 & 71,26 & 79,77 \\
\hline 15 & & BIHLB & 14,82 & 0,93 & 20,12 & 1,16 & 73,36 & 80,82 \\
\hline 16 & & BIMB & 15,65 & 1,01 & 19,10 & 1,34 & 73,98 & 80,17 \\
\hline 17 & & CIBB & 16,46 & 0,91 & 17,55 & 1,03 & 77,11 & 86,32 \\
\hline 18 & & HAMB & 17,81 & 1,75 & 13,89 & 0,84 & 82,37 & 96,67 \\
\hline 19 & & KFHB & 26,34 & 6,67 & 7,62 & 0,46 & 95,27 & 83,34 \\
\hline 20 & & MIB & 18,89 & 0,79 & 18,39 & 1,11 & 75,38 & 91,01 \\
\hline 21 & & OAABB & 17,25 & 2,75 & 16,32 & 1,13 & 79,29 & 73,91 \\
\hline 22 & & PIBB & 14,81 & 0,67 & 17,99 & 1,04 & 76,39 & 80,07 \\
\hline 23 & & RIBB & 15,11 & 1,08 & 13,37 & 0,85 & 73,41 & 82,91 \\
\hline 24 & & SCSB & 20,08 & 0,77 & 5,98 & 0,38 & 92,00 & 99,66 \\
\hline
\end{tabular}


Table 3. Statistics of Different Test Results

\begin{tabular}{|ll|r|r|r|r|}
\hline & Negara & $\mathrm{N}$ & Mean & Std. Deviation & Std. Error Mean \\
\hline CAR & Indonesia & 12 & 25,9242 & 17,30797 & 4,99638 \\
& Malaysia & 12 & 17,7117 & 3,31039 &, 95563 \\
\hline NPF & Indonesia & 12 & 4,8067 & 4,28665 & 1,23745 \\
& Malaysia & 12 & 1,6525 & 1,68504 &, 48643 \\
\hline NPM & Indonesia & 12 & 1,7133 & 12,49148 & 3,60598 \\
& Malaysia & 12 & 13,7642 & 5,73399 & 1,65526 \\
\hline \multirow{2}{*}{ ROA } & Indonesia & 12 &, 5192 & 3,28452 &, 94816 \\
& Malaysia & 12 &, 8525 &, 35856 &, 10351 \\
\hline BOPO & Indonesia & 12 & 97,2558 & 18,66064 & 5,38686 \\
& Malaysia & 12 & 79,3908 & 7,56759 & 2,18457 \\
\hline FDR & Indonesia & 12 & 7172,4800 & 24538,60354 & 7083,68468 \\
& Malaysia & 12 & 85,0767 & 7,46556 & 2,15512 \\
\hline
\end{tabular}

Table 4. Independent t-test Test Results

\begin{tabular}{|c|c|c|c|c|c|c|c|c|c|c|}
\hline \multicolumn{11}{|c|}{ Independent Samples Test } \\
\hline & & \multicolumn{2}{|c|}{$\begin{array}{l}\text { Levene's } \\
\text { Test for } \\
\text { Equality of } \\
\text { Variances }\end{array}$} & \multicolumn{7}{|c|}{ t-test for Equality of Means } \\
\hline & & \multirow[t]{2}{*}{$\mathrm{F}$} & \multirow[t]{2}{*}{ Sig. } & \multirow[t]{2}{*}{$\mathrm{T}$} & \multirow[t]{2}{*}{ df } & \multirow{2}{*}{$\begin{array}{l}\text { Sig. } \\
(2- \\
\text { tailed })\end{array}$} & \multirow{2}{*}{$\begin{array}{l}\text { Mean } \\
\text { Difference }\end{array}$} & \multirow{2}{*}{$\begin{array}{l}\text { Std. Error } \\
\text { Difference }\end{array}$} & \multicolumn{2}{|c|}{$\begin{array}{l}95 \% \text { Confidence Interval } \\
\text { of the Difference }\end{array}$} \\
\hline & & & & & & & & & Lower & Upper \\
\hline \multirow[b]{2}{*}{ CAR } & $\begin{array}{l}\text { Equal } \\
\text { variances } \\
\text { assumed }\end{array}$ & 5,379 &, 030 & 1,614 & 22 &, 121 & 8,21250 & 5,08695 & $-2,33719$ & 18,76219 \\
\hline & $\begin{array}{l}\text { Equal } \\
\text { variances } \\
\text { not } \\
\text { assumed }\end{array}$ & & & 1,614 & 11,804 &, 133 & 8,21250 & 5,08695 & $-2,89148$ & 19,31648 \\
\hline \multirow[b]{2}{*}{ NPF } & $\begin{array}{l}\text { Equal } \\
\text { variances } \\
\text { assumed }\end{array}$ & 2,483 &, 129 & 2,372 & 22 & ,027 & 3,15417 & 1,32962 &, 39670 & 5,91164 \\
\hline & $\begin{array}{l}\text { Equal } \\
\text { variances } \\
\text { not } \\
\text { assumed }\end{array}$ & & & 2,372 & 14,320 &, 032 & 3,15417 & 1,32962 & ,30838 & 5,99995 \\
\hline NPM & $\begin{array}{l}\text { Equal } \\
\text { variances } \\
\text { assumed }\end{array}$ & 3,200 & ,087 & 3,037 & 22 &, 006 & $-12,05083$ & 3,96774 & $-20,27943$ & $-3,82224$ \\
\hline
\end{tabular}




\begin{tabular}{|c|l|l|l|l|l|l|l|l|l|}
\hline & $\begin{array}{l}\text { Equal } \\
\text { variances } \\
\text { not } \\
\text { assumed }\end{array}$ \\
\hline ROA & $\begin{array}{l}\text { Equal } \\
\text { variances } \\
\text { assumed }\end{array}$ & $\begin{array}{l}\text { Equal } \\
\text { variances } \\
\text { not } \\
\text { assumed }\end{array}$ \\
\hline BOPO
\end{tabular}

Capital Adequacy

Judging from the results of hypothesis testing with Independent t-test shows the average variable CAR of Indonesia amounted to 25.9242 and Malaysia 17.7117 with a significance level of 0.133 . This provesthat Indonesia is better in terms of capital compared to Malaysia, although seen from the statistics it is not a significant difference. The reason is the significance value> 0.05 so that $\mathrm{HO}$ is accepted, meaning that there is no significant difference seen from the CAR ratio between Indonesian and Malaysian banks.

This research conducted by Rizkiyah \& Suhandak (2017) that compares the healthiness levelof Islamic banks in Indonesia, Malaysia, UAE, and Kuwait. The results showed, based on the CAR ratio there were no significant differences from thosefour countries. Other research conducted by Wibowo (2014) stated that there were no significant differences between the financial performance of Indonesian and Philippine Islamic banks. The same results were found in the research of Achan \& Chariri (2014), Wibowo (2015) and Hadi et al., (2019) who compared the performance of Indonesian and Malaysian Islamic banks with the same results, namely there was no significant difference between the financial performance of the two country.

The greater valueof CAR reflects the ability of banks to face the possibility of financial risks that possible tooccur. The growth of Indonesian shariabanks in general has indeed increased. From the data collected, it can be seen that the capital aspect has increased annually. This shows that IndonesiaGeneral Bank is quite good in protecting customers and maintaining overall financial stability. Under the terms of the Islamic Financial Service Board (IFSB), the minimum capital adequacy ratio is $8 \%$. From the data that has been obtained, the average CAR ratio of Indonesian and Malaysian Islamic banks over five years> 8\%, so it can be concluded that in terms of the performance of capital in Indonesian and Malaysian Islamic banks are in very good criteria.

Asset Quality

Based on the results of the hypothesis test with the Independent t-test that the asset quality variable which is proxied by the Non Perfoming Financing (NPF) ratio from the Group Satistics table shows the average NPF value of Islamic banks in Indonesia (4.8067) and Malaysia (1.6525). From this result, the difference is quite large, and the significance value of 0.027 is less than the critical limit of 0.05 . This shows that there are significant differences in the NPF ratio of Indonesian and Malaysian Islamic banks.

JURNAL ILMIAH KOMPUTERISASI AKUNTANSI Vol. 13, No. 1, Juli $2020: 88-99$ 
NPF ratio is the ratio of problem financing to total financing provided by Islamic banking. The smaller ofNPF ratio, the better of banks performancein managing credit given to their customers. Judging from the high average Indonesian NPF ratio, it reflects that Indonesian banks are experiencingproblem of managing and colleccting financing. Another factor that reflects the strengths of Islamic banking in Malaysia and Indonesia is the regulatory system in each country which greatly influences rapid growth ofIslamic banks. The very rapid development of Malaysian Islamic banking is driven by the government's responsiveness and accommodating in providing a legal framework for bank operations (Majid, 2014).

\section{Management Quality}

In the management component which is proxied by the Net Profit Margin (NPM) ratio, the performance of Malaysian Islamic banks is better than Indonesia. This is reflected in the results of the Independent t-test where the average value for the NPM ratio of Indonesian Islamic banks is 1.7133 while for Malaysian Islamic banks is much greater at 13.764. Then a statistical test is performed to determine whether this difference in value is significant or not. From the analysis results obtained a significance value of 0.006 well below the critical limit of 0.05 . It can be concluded that $\mathrm{H} 0$ is rejected because 0.006 $<0.05$ means that there is a significant difference from the NPM ratios of Indonesian and Malaysian Islamic banks. This previous comparative studies such as Rifai (2013) comparing the performance of 3 Islamic banks in Indonesia, as seen from the NPM ratio there are significant differences between the three banks.

The low average value of Indonesian bank NPM implies that operating income is large, while net profit after tax is still quite low, this is due to the high operational burden of Indonesian banks. At Malaysian banks with high average NPMs, they reflect the efficiency of banks in minimizing operational costs to increase operating income. Even though Indonesia is the largest Moslem country in ASEAN, the development of Indonesian Islamic banking seems slow compared to Malaysia. Strong political support in Malaysia is driving the rapid shariah banking industry, for example in careful preparation in pioneering the sharia banking industry both in regulation and management. Being in Indonesia with a lack of political support from the government at the beginning of the pioneering of Indonesian Islamic banks made the system of regulation and banking management weak (Majid, 2014).

\section{Earning}

From the earning aspect, it is proxied by two ratios, namely Return on Assets (ROA) and the ratio of Operating Expenses to Operating Income (BOPO). ROA ratio reflects the ability of banks to generate profits by utilizing the capital invested in all bank assets. BOPO ratio shows how efficient banks are in managing their operational activities.

Judging from the results of the hypothesis test with Independent t-test showed the average Indonesian ROA variable was 0.5192 and Malaysia was 0.8525 with a significance level of 0.733 . This shows that Indonesia is better in terms of capital compared to Malaysia, although seen from the statistics it is not a significant difference. The reason is the significance value $>0.05$ so that $\mathrm{H} 0$ is accepted, meaning that there is no significant difference seen from the ROA ratio between Indonesian and Malaysian banks. This finding was supported by previous researchers such as Widyawati \& Musdholifah (2018), Azzahroh et al., (2016), and Hadi et al., (2019), all of them statesthat there were no significant differences in the performance of Indonesian banks with other countries (Malaysia, Singapore, Thailand and the Philippines) in terms of the ROA ratio.

In general, Malaysian banks are better than Indonesia, in terms of asset growth. Shariah banking assets in Malaysia are RM 350.8 billion (USD 116 billion), and control 21\% of the market share (BNM Report, 2014). While Indonesia with total assets of Rp 104 trillion (USD 10.4 billion) has not reached 3.3\% of its market share (BI Report, 2011).

In the BOPO ratio, Malaysian Islamic banks performed better than Indonesia. This is reflected in the results of the Independent t-test where the average value for the BOPO ratio of Indonesian Islamic banks is 97.2558 while for Malaysian Islamic banks is much greater at 79.3908. The greater the value of BOPO, the more inefficient the performance of a company. Then a statistical test is performed to determine whether this difference in value is significant or not. From the analysis results obtained a significance value of 0.006 well below the critical limit of 0.05 . It can be concluded that $\mathrm{H} 0$ is rejected because 0.006 $<0.05$ means that there is a significant difference from the BOPO ratio of Indonesian and Malaysian Islamic banks.

These findings are supported by research conducted by Widyawati \& Musdholifah (2018), and Hadi et al., (2019) both of them statesthat there are significant differences between the financial performance of banks in Indonesia and Malaysia. This is in line with the study of Achan \& Chariri (2014) where there are 
also significant differences between the financial performance of pure and mixed shariahbanks around the world.

\section{Liquidity}

In the aspect of liquidity, the ratio of Financial to Deposit Ratio (FDR) is proxied. The FDR ratio reflects the ability of banks to pay withdrawals by customers using credit as a source of liquidity. The results of the hypothesis test with Independent t-test showed the average Indonesian FDR variable was 7172.48 and Malaysia was 85.0767 with a significance level of 0.339 . This shows that Indonesia is better in terms of capital compared to Malaysia, although seen from the statistics it is not a significant difference. The reason is the significance value $>0.05$ so that $\mathrm{HO}$ is accepted, meaning that there is no significant difference seen from the CAR ratio between Indonesian and Malaysian banks.

Judging from the FDR ratio with the average value of Indonesian banks which is higher than Malaysian banks, it shows that the performance of Indonesian banks in terms of liquidity is better than Malaysian banks. This is in line with research by Wibowo (2014), which states that the higher the FDR ratio, the better the level of liquidity. The ability of Indonesian banks to repay obligations to customers who have invested by withdrawing loans that have been given to debtors.

\section{Conclusions}

Based on the results of tests conducted to analyze the financial performance of Indonesian and Malaysian Islamic banks, it can be concluded that:

1. Based on testing using the CAMEL methodit is known that there is no significant differencebetween the performance of Indonesian and Malaysian Islamic banking as a whole.

2. Based on the average value of the results of the statistical test provesthat the performance of Indonesian banks is bettercompared to Malaysia in terms of CAR, ROA, and FDR ratios. Whereas from the ratio of NPF, NPM, and BOPO Malaysia is better than Indonesia.

3. Based on the results of statistical calculations with hypothesis testing, it shows that the ratio of NPF, NPM, and BOPO has a significant difference between the performance of Indonesian and Malaysian Islamic banks. whilethe CAR, ROA, and FDR ratios indicate that there are no significant differences in the financial performance of Indonesian and Malaysian Islamic banks.

4. The opportunity of Indonesian Islamic banking is still very large to develop and improve its financial performance, seenfrom the potential of Indonesia, it is possible to compete with other countries.

Limitations in the study are: The sample in the study did not take from all Islamic banking in both countries and the variables used as indicators of comparative financial performance are onlyfew.

\section{References}

[1] Achan, N. V. A., \& Chariri, A. (2014). Analisis Perbedaan Kinerja Keuangan Bank Syariah Murni dengan Bank Syariah Campuran pada Tahun 2011 dengan Menggunakan Metode CAMEL: Studi Kasus Pada Bank Syariah Diseluruh Dunia. Diponegoro Journal of Accounting, 3, 631-641.

[2] Andrianto, \& Firmansyah, M. A. (2019). Buku Manajemen Bank Syariah. In CV. Penerbit Qiara Media (Issue September).

[3] Azzahroh, M., Hidayat, R. R., \& Sulasmiyati, S. (2016). Analisis Komparatif Kinerja Keuangan Bank Umum di Indonesia dan Malaysia ( Studi pada 3 Bank Umum Terbesar di Indonesia dan Malaysia Tahun 2010-2014 ). Jurnal Administrasi Bisnis, 35(2), 65-71.

[4] Ghozali, I. (2016). Aplikasi Analisis Multivariete dengan Program IBM SPSS 23 (Edisi 8). Cetakan ke VIII. In Badan Penerbit Universitas Diponegoro. https://doi.org/10.1021/ol7029646

[5] Hadi, S., Mulyana, P. A., \& Mahardhika, B. W. (2019). Analisis Perbankdingan Kinerja Keuangan PT. Bank Mandiri (Indonesia) dan Malayan Bank BHD (Malaysia) Periode Tahun 2013-2017. Jurnal Balance, XVI(2), 234-246.

[6] Jacob, J. K. D. (2013). Analisis Laporan Keuangan dengan Menggunakan Metode CAMEL Untuk Menilai Ingkat Kesehatan Perbankan. Jurnal EMBA, 1(1), 691-700. https://doi.org/10.1007/s13398-014-0173-7.2

[7] Kaligis, Y. (2013). Analisis Tingkat Kesehatan Bank dengan Menggunakan Metode CAMEL pada Industri Perbankan BUMN yang Terdaftar di Bursa Efek Indonesia. Jurnal Riset Ekonomi, Manajemen, Bisnis Dan Akuntansi, 1(3), 263-272.

[8] Kuncoro, M. (2011). Metode kuantitatif: Teori dan Aplikasi untuk Bisnis dan Ekonomi. In Unit penerbit dan percetakan SEKOLAH TINGGI ILMU MANAJEMEN YKPN.

JURNAL ILMIAH KOMPUTERISASI AKUNTANSI Vol. 13, No. 1, Juli $2020: 88$ - 99 
[9] Majid, S. A. (2014). Regulasi Perbankan Studi Komparatif Antara Malaysia dan Indonesia. Media Syariah, XVI(1).

[10] Novera, W. (2017). Tingkat Kesehatan Perbankan Syariah: Studi Komparatif Indonesia dan Malaysia. Skripsi.

[11] Novita, N., Akbar, A. S., \& Handayani, P. D. (2016). Analisis Kebangkrutan Bank melalui Rentabilitas, Capital dan Bankometer: Studi pada Bank Umum Indonesia dan Malaysia. Jurnal Ekonomi, Manajemen Dan Perbankan, 2, 11-17.

[12] Paputungan, D. F. (2015). Penilaian Tingkat Kesehatan Bank Menggunakan Metode Camel Pada Pt. Bank Rakyat Indonesia Cabang Manado Periode 2010-2015. Jurnal EMBA, 4(3), 729-740.

[13] Rastogi, S., \& Singh, V. (2017). Analysis of Public Private Sector Bank Performance Using CAMELS Model: A Longitudinal Study. International Jurnal of Research in Economics and Social Sciences (IJRESS), 7(11), 480-491.

[14] Rifai, A. (2013). Analisis Perbandingan Kinerja Keuangan Bank Syari'ah Menggunakan Pendekatan Income Statement (ISA) Dan Value Added Reporting (VAR). Accounting Analysis Journal, 2(1), 19-26. https://doi.org/10.15294/aaj.v2i1.1182

[15] Rizkiyah, K., \& Suhandak. (2017). Analisis Perbandingan Tingkat Kesehatan Bank Berdasarkan Risk Profile, Good Corpoorate Governance, Earnings dan Capital (RGEC) Pada Bank Konvensional BUMN dan Swasta (Studi pada Bank Umum Milik Negara dan Bank Swasta Nasional Devisa yang Terdaftar di Burs. Jurnal Administrasi Bisnis, 43(1), 163-171.

[16] Wibowo, S. (2014). Perbandingan Indikator Kinerja Keuangan Perbankan Syariah di ASEAN (Studi Komparatif: Indonesia, Filipina, Brunei Darusalam). Economic \& Business Research Festival, 9, 285-302. https://doi.org/10.1017/CBO9781107415324.004

[17] Wibowo, S. (2015). Analisis Perbandingan Kinerja Keuangan Perbankan Syariah dengan Metde CAMEL di ASEAN (Studi Komparatif: Indonesia, Malaysia, Thailand). Jurnal Riset Ekonomi Dan Manajemen, 15(1), 136. https://doi.org/10.17970/jrem.15.1501010.id

[18] Widyawati, W., \& Musdholifah, M. (2018). Analisis Komparatif Tingkat Kesehatan Perbankan dengan Metode CAMELS di ASEAN (Studi pada Bank Umum Indonesia, Malaysia, Singapura, Thailand, dan Filipina Tahun 2012-2016). Jurnal Ilmu Manajemen (JIM), 6(4), 531-541. 